\title{
Power in The Tradition of Kain Timur Exchange: A Study of Using Tradition to Get Support in the Local Election in South Sorong 2010 ${ }^{1}$
}

Haryanto

\begin{abstract}
The tradition of kain timur requires the receiver party to reimburse the value of a gift. This exchange tradition has the potential to become an instrument to gain support in local elections. The ability of the candidates in making use of this resource becomes the key to success in applying the exchange of kain timur tradition as an instrument to gain power. This can be seen in South Sorong, in which a candidate could successfully become the winner in local election in 2010 by using the exchange of kain timur tradition.
\end{abstract}

Keywords: exchange tradition; gain support; the actor's ability (candidate); power.

\section{Opening Remarks}

This writing was inspired by the awareness that the efforts to gain power will never exist in a vacuum. It happens in the sociocultural, socio-economic, and socio-political settings. The political practice to fight to gain power cannot be separated from the setting in which the fight for power is happening. As one of the sociocultural settings, the existence of tradition can influence the efforts to gain power through the election mechanism. This writing aims to study the existence of the tradition of exchange that is used as an instrument to gain power.

Tradition can be used as a study because so far as the writer understands, studies related with socio-cultural setting as an effort

Data for this article was collected during the author's doctoral research at the Social and Political Sciences at Universitas Gadjah Mada between 2009 and 2011. More detail analysis of this article could be found in the author's book 'Politik Kain Timur "Instrumen Meraih Kekuasaan"' (PolGov, Department of Politics and Government, FISIPOL UGM, 2015). 
to gain power are more on the study of political identity. The local politics in Indonesia tend to be coloured with the work of political identity in trying to explain the effort to gain power. Those studies among others were done by Andrianto (2001), Sugiono (2001), Syarkawi (2007), and Ramandey (2008). Therefore, this writing will not do the same as these studies, which focus on political identity, but this writing will study about efforts to gain power seen from a different point of view, especially from the socio-cultural aspect, that is the tradition of exchange, which has been in the community.

In this context, tradition is considered as customs referring to habits, which are used as the guidelines to interact among members of the community. In relation to this, referring to the categorisation which is stated by Helmke and Levitsky (2004; 728-729), tradition can be categorized as an informal institution because of the way it is formed by the community themselves. As an informal institution, tradition can be used as an instrument to gain support (mobilization) in order to gain power that is done by the local election mechanism known as Pemilihan Kepala Daerah (Pilkada).

The tradition being studied in this writing exists among the community in South Sorong, West Papua. Tradition in South Sorong community can be said to be relatively strong. The strength of values in the tradition cannot be separated from the relatively salient similarities of the ethnic identities existing in the Papua community in general. ${ }^{2}$ Field realities indicate that the traditions that still exist in the daily practices of Papua contribute to the prominence of ethnic identities and at the same time, the ethnic identities also support the continuity of the traditions in the community. In relation to this, it

The thickness of Papua identities can be seen from 3 (three) aspects: one, the issue of separatism based on the identity differences between people from Papua and from outside of Papua. Two, the enactment of Laws No. 21 year 2001 about Special Autonomy for People from Papua which regulate about the form of Majelis Rakyat Papua (MRP, Assembly of People from Papua) as the cultural representation of native inhabitants of Papua, and which required the Governor position by the native Papua. Three, there is an issue the native indigenous Papua and the non-indigenous Papua in the mechanism of gaining power through Pilkada in some districts in Papua. 
is not too much if it is claimed that the prominence of the identities is correlated with the prominence of the tradition in the community. Between these two, the strength of ethnic identities and the strength of the traditions simultaneously support each other to strengthen their existence.

The tradition studied in this writing is the exchange tradition of kain timur which is still in practice in South Sorong until now, and which is prominent with its ethnic identity. The exchange tradition of kain timur can still be felt until now and becomes a stable reference for the South Sorong community for a relatively long time span (Mansoben, 1994). This exchange tradition does not only contain economic values which guide the community in terms of exchange (debts and receivables) and investments (savings), but also contains socio-political values that guide the community in the decision-making process.

Based on the previous argument, this writing explains the essence of the exchange tradition of kain timur which is still used to gain political power. To describe how the exchange tradition of kain timur happens and how it is used to gain power, this article focuses on one of the strategies used by a candidate of the local election in South Sorong in 2010, Otto Ihalauw. The election of Otto Ihalau as an actor is selected to explain how the essence of the exchange tradition of kain timur works and is not without reasons.

First, Ottow Ihalau was the first-choice incumbent candidate. This means, that the resources he owned were more than the ones owned by other candidates. The ownership and ability to use these resources became the key points for the triumph of Otto Ihalauw. Second, Otto Ihalauw knew the exchange tradition of kain timur that existed in the South Sorong community. Third, Otto Ihalauw was the candidate from a non-Papua ethnic. Therefore, based on these arguments, this article tries to see how the exchange tradition of kain timur is used as an instrument to gain and maintain power by using Otto Ihalauw as the proxy. 


\section{Exchange Tradition of Kain Timur}

In its form, kain timur is not more than a type of kain ikat ('ikatcloth') that can be found in 'kepala burung' Papua (the 'vogelkopt' of New Guinea) inland. One study done by Elmberg, Pouwer, and Kamma is used as reference by Mansoben (1994) in identifying the history of kain timur. Mansoben claimed that kain timur was from Nusa Tenggara island and Maluku island, and it is estimated to enter the 'kepala burung' area since the first half of the 16th century (pp. 75-76). Kain timur entering 'kepala burung' area and west coast Papua could be traced by the trading activities done by the traders from Nusa Tenggara and Maluku. By means of these trading activities, finally kain timur which was in the west coast of Papua continued entering the 'kepala burung' inland area.

The existence of kain timur can be differentiated into 2 (two) categories; they are what are considered sacred and profane (Mansoben, 1994: 73-74; Massink, 2001: 475-477; Sanggenafa \& Koentjaraningrat, 1994: 162-166). Kain timur which is categorized as sacred is kain timur which is considered holy and is called wan or heirloom fabrics. Wan functions as magical-religious fashion. This fabric is owned through hereditary, passed from father as the oldest son to the oldest son and this fabric can be used to communicate with the ancestors. The contact with the ancestors is done in the skull home where the skulls of the ancestors are kept, which is called as sachefra.

Kain timur is considered to have magical-religious values because it takes the role as a medium, for example in ritual ceremonies, praying skulls ceremonies and wedding ceremonies. By means of kain timur, ritual ceremonies are believed to bring the spirits of the ancestors to ask for help and safety. It also happens when the owner is in difficulties, for example one of the family members is sick or fails to get harvest, kain timur which is categorized as wan or heirloom fabrics can be used by spreading it in the sachefra while asking to be freed from the difficulties that they are facing. However, as mentioned previously, kain timur which has magical-religious 
values cannot be exchanged but only inherited as a cloth which is considered sacred.

Meanwhile, kain timur which is considered as profane is kain timur which does not have magical-religious values. Profane kain timur is called bo or kain jalan. ${ }^{3}$ Profane kain timur has a socioeconomic function, and can be used in exchange relationship as a gift, in wedding ceremonies as a means to pay for dowry, and in trading activities as a medium of exchange. As a medium of exchange in trading, kain timur can bring special profit or interest for its owner.

The benefits gained from exchanging kain timur is not necessarily economical; however, it can be socio-political. As a medium of exchange, kain timur can be used to increase the status or prestige of its owner. The success in exchange can make someone have a lot of kain timur and the more kain timur someone has, the higher the status and prestige of the owner, which then enlarges their influence. The success in collecting kain timur is considered as the achievement of social strata which culminates in the ability to influence the decision-making process in the community. Another aspect that needs to be explained from the exchange of kain timur is the one related with someone's pride or prestige. It means that the ownership of kain timur is a symbol that represents the success and influence of someone, not only socially and politically, but also economically. Therefore, it is not too much if it is claimed that kain timur has magical-religious, economic and socio-political values.

In its function as a medium of exchange, kain timur hints the presence of tradition in which the party who receives the gift is supposed to give a bigger amount of refund. In relation to this, Boellaars (1986) explains that the opening gift is followed by giving a reply which is more valuable, and this gift is followed by the gift

Profane Kain timur which functions as the payment of dowry and as means to pay is called by Maybrat people with ru-ra, which means a human bird, because it needs to fly and gives benefits (Mansoben, 1994, pp. 74-75), which is quoted from the study of Elmberg, Schoori, and Miedema). 
of inaugural award. If the party who receives it neglects or ignores the responsibility to give refund, the related party will get penalty. Penalty is given so that the effort done by the party who gave it will get the refund. The penalty is not only in the form of anger from the party who gave it, but also in the form of physical threat that might lead to death.

In its development, the exchange of kain timur includes a small number of people who have the best quality of kain timur in a large amount. These small number of people who are able to collect a large number of kain timur make themselves as bobots. With this title, a bobot sometimes has the authority to be the ethnic leader because this person has a lot more kain timur than other people. "The ownership of kain timur by a bobot presents a patronclient relationship between a bobot and the other people who are not bobots" (Mansoben, 1994, p.78). Bobots take the role of patrons, and the community members who are not bobots take the role of clients.

The achievement of social strata cannot be separated from the existence of 'kain timur complex' as it is explained by Mansoben (1994). 'Kain timur complex' refers to the exchange system in the establishment of social unity which is larger than the self-support economic system (p.71). This is because kain timur can work through the social unity which is based on clan groups so that it represents the social unity based on the traditional exchange system of kain timur. Therefore, it is not surprising if it is studied based on the traditional leadership typology. As it is explained by Mansoben (1994), South Sorong has dignified leadership typology (local big-man). ${ }^{4}$

4 In commanding man or the local big-man leadership, a leader gain his position by the efforts, and not based on the line of decent. Someone he can be a leader if he can collect a great amount of kain timur. In order to lead a person needs to be rich, kind and smart in diplomacy (good in speech) in the context of exchange and circulate kain timur (Mansoben, 1994, pp. 61-115). 


\section{The Tradition of Kain Timur Exchange and the Effort to Gain Power}

The exchange of kain timur has been happening for a long time. Therefore, the exchange of kain timur has been the tradition and become the norm in the daily life of the community in "kepala burung' inland Papua, especially in South Sorong. As mentioned previously, the essence of the exchange tradition of kain timur is the hint for the existence of the responsibility of the receiver party to give refund and the refund should be followed with the interest as the addition. This means that the exchange of kain timur is mutually reciprocal and binding, either for the party who gives it or the party who receives it. This is because both parties get the responsibility to return as long as both still accept the gift. Meanwhile, the process of giving and taking should not stop and continuously happens with greater amount than the previous ones. If the party who receives it neglects or denies those responsibilities, the related party will get social penalty even physical threat (Haryanto, 2015). The essence of this exchange tradition can be explained parallel with the concept of giving a present or donation as it is said by Mauss (1990) and Hyde (1983) as a gift. The concept of gift presents the giving, receiving and returning concepts that is accepted in a continuous process.

In its practice, the tradition of the exchange of kain timur, in addition to the form of binding relationship between the giving and receiving party, there is also a transactional dimension. ${ }^{5}$ This transactional dimension happens through the exchange process, which is sometimes economical. This is because the party who receives it feels burdened by the responsibility to return a gift with a bigger and more valuable refund. At this point, this means that the giver party will get more benefit in the process of refunding because the refund will be bigger and more valuable than the previous ones.

The transactional principles in 'profane' kain timur in its function as a means of exchange; the transactional prinsiples in 'sacred' kain timur in its function as ritual needs related with the ancestors. 
In other words, the more the giving actions, the more benefits one will get from the refund.

This explanation is strengthened by Mansoben, who mentioned that the transactional process does not only have the economical dimension but also is centered on the political dimension. Mansoben (1994) explained that "politically the gifts in any forms become the modal (investment) for the giving party to bind the receiver party to gain the political purpose of the giving party" (p. 63). This can be interpreted that the more one gives, the more political supports go to the giver. In this context, gathering the electoral political power, transactional relationship in the exchange of kain timur can be described by the relationship of reciprocal benefit among the actors who try to get the power by sounding the community that is needed by the actors. In its practice, the exchange of kain timur tradition which is indirect and continuous can be illustrated as follows:

\section{Relationship Mechanism}

Based on the Essence of the Exchange of Kain Timur Tradition

Direct relationship

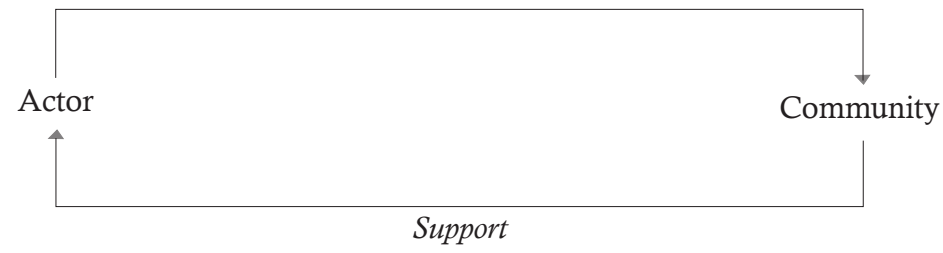

Indirect relationship

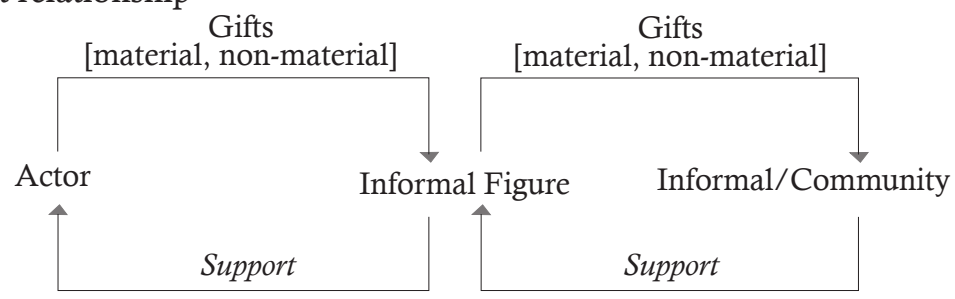


The combination of direct relationship and indirect relationship

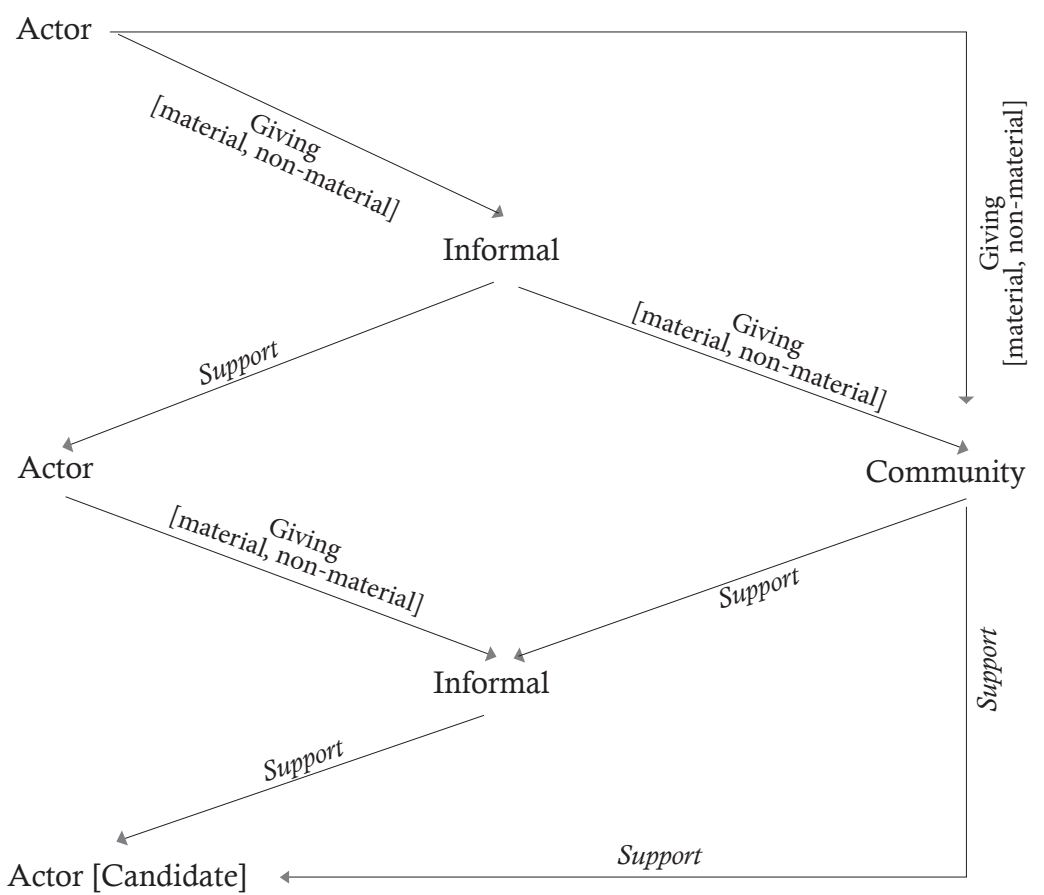

In this diagram, indirectly, the mechanism of the exchange also indicates the political phenomena that happens in the process of electoral politics, that is the patronage phenomena as described by Kitschelt and Wilkinson (2007). In the mechanism of the exchange relationship, the party who gives takes the position of a patron and the party who receives it takes the position of a client and between those two reciprocal benefits happen. In relation with this study, in order to avoid bias, the concepts of patron-client and patronage are interchangeable to reveal the relationship of the exchange of kain timur. In addition, it is important to explain that in kain timur exchange tradition between patron and client, the relationship is not necessarily hierarchical and profitable for the patron only as it is explained in previous studies.

Moreover, based on the observation of patron-client 
relationships in the tradition of the exchange of kain timur, at some levels a client is placed as less passive and relatively at the same level as the patron (Simandjuntak, 2012). For example, in one of the cases the relationship between patron-client was disconnected because the patron did not have legitimation and strong resources after he did not hold a particular position anymore. In addition, as it is mentioned in the relationship of kain timur, the supports can only be given to the patron, and not to the person who is chosen or who represent him. Therefore, the exchange of kain timur does not only form the patronage relationship which is reflected in the goods exchange in which in the context of electoral politics can be in the form of either material or non-material giving between the patron and client, but also reciprocal benefits which is relatively at the same level and less passive.

Even so, the mechanism of the relationship of the exchange of kain timur which appears in the form of direct and indirect relationship indicates the relationship happening among actors in the exchange of kain timur (see the previous figure). The pattern of direct relationship reveals the actor who tries to gain power taking the position of the giver and the community taking the position of the receiver. The actor gives either material or non-material gifts to the community. The community returns the gifts in the form of support for the actor. Then, the actor receives the return, in order to keep the support from the community, will give more than the first giving and the community will do more to support the candidate. Therefore, the mechanism of the relationship continuously and reciprocally happens.

The indirect relationship happens when the figure who takes the role of intermediator appears in the exchange transaction relationship. This figure is sometimes paid by an informal figure (ethnic figure) in the community. Beginning with the relationship between the actor who takes the position as the giver and the mediator figure who takes the position as the receiver. An actor gives something, either in the form of material or non-material giving, to 
the mediator figure. Then the mediator figure played by the informal figure creates a relationship with the community. The mediator figure (informal figure) in his position as a patron gives something to the community, and the community in their position as clients return the gifts they have received by showing their obedience in the form of supports to the informal figure. This return in the form of supports from the community, initiated by the mediator figure is directed to the actor as the return for something that he has received. The return is in a bigger amount and more valuable.

Therefore, the exchange of kain timur tradition presents the relationship which tends to be transactional and creates patronage between the giver and the receiver parties. As it is illustrated previously it can be interpreted as savings or investments for the future. These savings or investments will bear fruit in the form of return from the informal figure or from the community in the form of supports. Politically, the gifts in any forms can be the savings or investments for the giving party to bind the receiver party to support the political purpose of the giving party. The more the party gives, the more supports from the receiver they will get. On the other hand, the less the party gives, the less supports (voice) given to the giving party. The following excerpts explain the essence of the exchange of kain timur tradition as an instrument used by Otto Ihalauw to gain support in Pilkada in Sorong 2010.

\section{The Exchange of Kain Timur Tradition: An Instrument to Gain Power in South Sorong}

Before discussing the exchange of kain timur tradition as an instrument to gain power through the mechanism of Pilkada, this passage describes the setting of South Sorong briefly. In addition to the description of the existence of the ethnic groups, this passage also presents the profile of the actors who contested in the Pilkada held in 2010. This description is ended with analyses related with the ability of the successful actor who made use of the exchange of kain timur tradition as an instrument to gain supports in Pilkada 2010. 


\section{The Setting of South Sorong}

As one of the districts located in 'kepala burung' area, the community in South Sorong consists of some ethnic groups (Miedema \& Reesink, 2004) ${ }^{6}$. They can be categorized into various groups based on whether they are from Papua as their origin or new comers who are non-Papuan. Those who are included into the Papuan group in the South Sorong district are Tehit, Imekko, and Maybrat.

The composition of the number of the members of Tehit, Imekko and Maybrat are relatively even. However, as Maybrat has separated becoming a new district, the composition of the number of members of Maybrat ethnic is slightly changing ${ }^{7}$. This is because Maybrat people moved becoming the people in the Maybrat district and some of them remained staying and domicile in South Sorong district.

In addition to the Papuan ethnic group, the presence of new comers from outside can also be found in South Sorong. In general, the new comers were from Java, Sulawesi, Maluku and Nusa Tenggara Timur. Their numbers are relatively smaller compared with the native inhabitants. The following table illustrates the distribution of the ethnic group in South Sorong.

6 The existence of Papua ethnic groups is an aspect that cannot be denied. Miedema and Reesink (2004). in their book entitled One Head, Many Faces illustrated that Kepala Burung area, located in South Sorong, can be found some ethnic groups whose names are based on the area consideration or based on the domicile of the groups, language or dialect of the groups, the leader's names or the group figures, or the new names from outside of the groups (pp. 9-11).

7 Maybrat became the new district based on Laws No 13 Year 2009 about the Form of Maybrat district. 
Table: Ethnic Group Comparison

\begin{tabular}{|c|c|c|}
\hline Ethnic Groups & Districts (domicilies) & Total (Estimates) \\
\hline $\begin{array}{cl}\text { Tehit: } & \\
- & \text { Tehit } \\
- & \text { Sawiat } \\
\text { - } & \text { Imyan } \\
- & \text { Salakhma } \\
\text { - } & \text { Saifi } \\
- & \text { Ogit }\end{array}$ & $\begin{array}{l}\text { - } \text { Teminabuan and } \\
\text { - Seremuk } \\
\text { - Sawiat, Fkour } \\
\text { - Seremuk } \\
\text { - } \text { Sawiat } \\
\text { - } \text { Saifi } \\
\text { - } \text { Konda }\end{array}$ & $35 \%$ \\
\hline $\begin{aligned} & \text { Imekko: } \\
& \text { - } \text { Bira } \\
&- \text { Iwaro } \\
& \text { - } \text { Negiro/Mate } \\
& \text { - } \text { Kaiso } \\
& \text { - } \text { Ameyode } \\
& \text { - } \text { Awee }\end{aligned}$ & $\begin{array}{l}\text { - Inanwatan } \\
\text { - Matemani } \\
\text { - Matemani } \\
\text { - Kais } \\
\text { - Kokoda } \\
\text { - Kokoda Utara }\end{array}$ & $35 \%$ \\
\hline $\begin{array}{l}\text { Maybrat: } \\
\text { - Ayamaru } \\
\text { - Aifat } \\
\text { - Aitinyo }\end{array}$ & $\begin{array}{l}\text { - Moswaren } \\
\text { - Wayer }\end{array}$ & $20 \%$ \\
\hline Non-Papua *) & $\begin{array}{l}\text { - Teminabuan } \\
\text { - Moswaren }\end{array}$ & $10 \%$ \\
\hline
\end{tabular}

Sources: field data, processed

Notes: *) Non-Papua people consisted of people from Java, Bugis, Buton, and Makassar (known as BBM), and some people from Ambon.

Although each ethnic group tends to live in a colony in a particular area, in their daily life, one ethnic group will not be separated from the other ethnic groups. They interact in the market to fulfil their economic needs and they meet in the health centre when they need health service and even their children go to the same school (Sija, A., interview, July 17, 2010). ${ }^{8}$ The life continuity that blends among different Papua ethnic groups and the new comers cause South Sorong community to be considered as an ethnicity-

Ansar Sija, with a newcomer ethnic group background interview in Teminabuan - South Sorong. 
based community.

The relationship pattern among South Sorong community members that is ethnicity-based cannot be separated from the context of the community there which tends to be heterogeneous. This context causes primordialism to become strong especially because of the similarity of the blood, religious, language and especially the tradition which is articulated in the kain timur exchange (Haryanto, 2015). Nevertheless, this strong ethnicity which then peaks as Papua indigenous primordialism is used as an instrument by actors to mobilize and gain supports (Haryanto, 2015, p. 28). In such relationship, patronage as the strategy to gain support in Pilkada becomes possible.

Moreover, in the context of natural conditions in South Sorong especially to fulfil daily needs for the community who live similarly with gathering culture becomes prominent. This condition causes South Sorong people to have the character that easily changes depending on the natural condition. Especially when they intend to choose from the possibilities, they tend to choose ones that can give the biggest benefit. At this point, we can say that this character becomes one of the driving factors for the patronage-based relationship to happen.

\section{Otto Ihalauw: An Actor who Contested in Pilkada $\mathbf{2 0 1 0}$}

Otto Ihalauw was one of the candidates who joined the competition to get the position as the district head in South Sorong through the Pilkada mechanism in 2010. Being in a non-Papua ethnic group that is Ambon (Maluku), Otto Ihalauw was born and grew up in Papua. His background took an important role in forming Otto Ihalauw to be a simple and religious individual. From this father's line, his grandfather was a religious figure and at the same time was a missionary in South Sorong, and from his mother's line, his grandfather was known to be an educator. Meanwhile, his father was a career bureaucrat in the ranks of local government. Therefore, it is not surprising that the life of bureaucracy had been 
familiar to him since he was a child.

His educational background began with Otto Ihalauw going to primary school and middle school in Manokwari, meanwhile his high school was in Sorong until 1977. His higher education was in Jayapura in which Otto Ihalauw finished his Diploma III in Akademi Pemerintahan Dalam Negeri (Government Domestic Academy, APDN). In 1981, and then continued in Institut Ilmu Pemerintahan (Institute of Science of Government, IIP) Jakarta which was finished in 1989. Amid a bustle as a local government official, Otto Ihalauw tried to attend Masters Program in Political Science in Universitas Gadjah Mada focusing on Local Politics and Regional Autonomy which he finished in 2011.

His career in government bureaucracy began after Otto Ihalauw finished his study in APDN, Jayapura. His career as a bureaucrat could be considered without significant challenge. This is seen from the records in which Otto Ihalauw began from becoming a staff until he got a structural position in a relatively short time period. In addition to getting a structural position as a head of a department, Otto Ihalauw had been a head of a region, that was camat or district head of Teminabuan. The experience of becoming the head of the district apparently gave him a special experience which was more valuable for Otto Ihalauw in terms of communicating with the community.

One aspect that needs to be noted in the career journey of bureaucrats is his inauguration as the indigenous child of Tehit (one of the indigenous ethnic groups in South Sorong). The inauguration as the indigenous child of Tehit made the person accepted as the original Papua. Although having a status as indigenous child of Tehit, Otto Ihalau did not treat this ethnic group differently. He continued making efforts in treating this ethnic group in relatively the same way without considering their descent (Momot, M., interview, July 19, 2010). ${ }^{9}$ This treatment and behaviour created a positive image

9 The interview with Michael Momot (The head of Indigenous Council of Tehit) in 
in the community that Otto Ihalauw was a bureaucrat who was able to lead without favouring one ethnic group.

The political career of Otto Ihalauw began when he was inaugurated as the head of the district of South Sorong in 2003. After approximately 2 years becoming the head of the district, Otto Ihalauw decided to join Pilkada for the election of definitive head of the district election which was held in 2005. Otto Ihalauw successfully won in Pilkada, and became the head of the district of South Sorong 2005-2010 period. In the amidst of his bustle as the head of the district, Otto Ihalauw also became the head of Golkar Party in South Sorong.

The previous description indicated that Otto Ihalauw had some of resources that could be used to gain and defend political power. At least, Otto Ihalauw had 3 of 5 types of resources as stated by Andrain (1992, pp. 132-135) ${ }^{10}$, that is the normative, personal and skill power. The normative resources were in the form of the authority which were attached to himself as the head of the district. Moreover, the authority as the head of Golkar Party was also considered as a normative resource for Otto Ihalauw. Additionally, his status as the child of Tehit was considered to be a normative resource owned by Otto Ihalauw.

Personal resources that were owned by Otto Ihalauw were in the form of personal character as a simple, open, kind-hearted, and easy-going figure. This personal resource as a political figure cannot be separated his family background that was simple and religious. In addition, another important personal source of Otto Ihalauw was his decent as a non-Papua when he proposed himself to be the head of the district of South Sorong. At this time people

Teminabuan - South Sorong, In the interview, Michael Momot stated that "Otto Ihalauw diangkat sebagai anak adat Suku Tehit, tetapi ia memberi perlakuan sama ke semua kelompok etnis. Kelompok etnis asli ataupun pendatang diperlakukan sama". ("Otto Ihalau was adopted as the son of Tehit clan, but he treats the other ethnic groups the same ways. Either the indigenous ethnic groups or new comers are treated the same way.")

10 Andrain (1992) stated that 5 types of sources, they are physical, economic, normative, personal and skills (informational) sources (pp. 132-135). 
who were non-Papua were more beneficial because one, the trust relationship of indigenous Papua to the non-Papua was more than to the indigenous Papua themselves. This was because when one of the Papua ethnic groups wins the Pilkada, all of the resources would go to and benefit only one of the indigenous ethnic groups. It means that there had been exclusivism among indigenous ethnic groups of Papua especially in gaining resources. Two, when Otto Ihalauw proposed himself as the district leader, two indigenous people from the same ethnic group proposed themselves to be the district leaders so that more people elected Otto Ihalauw to be the district leader.

Meanwhile, the skill resources owned by Otto Ihalauw was in the form of knowledge and technical skills in governmental aspects. These resources were gained through his education that he took in APDN, IIP, and Local Political Program and Regional Autonomy (Pasca Sarjana-UGM). The skill resources were also gained through his career journey in the bureaucracy until he gained the political position as the head of the district of South Sorong in 2005-2010.

Meanwhile, Otto Ihalauw's understanding about the South Sorong community and their tradition was considered sufficient. Otto understood the reality that the essence of exchange kain timur tradition became the reference of the community in their daily life, especially the one related with one's ability in collecting a great number of kain timur that causes the person to be considered as holding the position and influence in his community (Ihalauw, O., interview, July 21,2010$)^{11}$. In relation to this, Otto was also aware that the mechanisms of exchange in the kain timur tradition could be used to gain influence that finally could be implemented in gaining the supports in order to gain power. The understanding that the exchange in the kain timur tradition that can be used as an

11 Otto Ihalauw's understanding about the exchange of kain timur was identified by the interview with him in Teminabuan - South Sorong. In the interview it was stated that "orang yang mempunyai kain timur dalam jumlah banyak akan mempunyai pengaruh di masyarakat; semakin banyak kain timur yang dimiliki akan menjadikan semakin besar pengaruh pemiliknya" ("someone who owns a great number of kain timur will get more influence in the society; the more kain timur he has, the more the influence he has.") 
instrument to materialize the political needs implicitly appeared in his statement that said, "the gift that was done is the model to bind the other party in order to get political support from a lot of the givers (Ihalauw, O., interview, July 21, 2010)." ${ }^{12}$

Otto Ihalauw's understanding about the exchange of kain timur tradition was completed with the understanding about gathering culture that existed in the community. Like indigenous Papua in general, the ethnic groups in South Sorong also know the gathering tradition. The gathering tradition indicates that the community has the habits to find food by cultivating an unirrigated field from one place to another. If a particular place does not bare food anymore, the field will be left and they move to another place that is more promising. The essence of gathering tradition, if it is matched with the exchange of kain timur tradition, is that the community will only receive the most beneficial gift. When both parties or more offer a gift, therefore only the gift that is accepted is only the one that is valuable; and the gift that has been accepted will be returned together with the interest as its addition.

In the context of Pilkada, Otto Ihalauw was aware and understood that the community in South Sorong strongly tended to not accept both or more gifts which were offered by the candidates who competed. Otto Ihalauw believed that the community would only accept one of the gifts. This was because the community did not want to get burden to return the gift in the form of support toward the candidates who lost in the Pilkada contestation. The gifts that was offered by other candidates were rejected because it is impossible for the community, at the same period, to give supports to two or more candidates. The community will only receive the gifts that were thought to be the most beneficial for them. Otto Ihalauw realized and understood that the behaviour of the community referred to the essence of the exchange of kain timur tradition and the gathering tradition.

12 The interview with Otto Ihalauw in Teminabuan - South Sorong. 


\section{The Actor's Ability, Instrument Tradition, and the Efforts to Gain Support in Pilkada}

As an actor who contested in Pilkada, Otto Ihalauw tried to gain support to be the winner in the contestation of Pilkada. The raising of supports was done by Otto Ihalauw in every life activity in the form of government activities in bureaucracy, politics and communities. The raising of supports was done far before the election was held and happened over a relatively long period. Meanwhile, Otto Ihalauw also raised the supports through election activities including the steps of campaigns and election/ voice counting.

The raising of supports in government and communities' activities, also the activities in election could not be separated from each other. The raising of supports in those activities accumulated to be one energy to win the Pilkada to gain power. In raising the supports, Otto Ihalauw used the exchange of kain timur tradition as an instrument; and the use of the instrument was done based on the resources that he owned. In order to win the Pilkada, Otto Ihalauw as the actor who tried to gain power was expected to be optimal in using the exchange tradition as an instrument to gain supports.

\section{a) The Raising of Supports in Bureaucracy}

In his position as the candidate incumbent, Otto Ihalauw had the normative resources in the form of his right to manage and lead the government bureaucracy. Based on this right, Otto Ihalauw used the bureaucracy to gain supports from the community. The first step that he took was gaining supports from the bureaucracy themselves and then the bureaucracy was used to gain supports from the community. With the right resources as the head of the district, the support raising at the bureaucracy was done by Otto Ihalauw by considering the representativeness of the ethnicity.

The explanation is, by applying the principle of representativeness of the ethnic groups means that each ethnic group would gain voice in the structural position in the bureaucracy. For these ethnic groups, the replacement of the members in the 
structural position is interpreted as the gifts from Otto Ihalauw and the ethnic groups were attached to the responsibility to return the gifts. The returning process was done by the members of the groups who were in the structural position. The return was in the form of raising the supports done by the officials towards the ethnic groups in which the related people were from.

The filling of the structural bureaucracy other than considering the representativeness of the ethnicity was considering the community perception related with the bureaucracy position. The community assumed that the bureaucracy position had a high social status and was able to indicate the existence of a particular ethnic group. A bureaucrat who was in the structural position was considered to be able to increase the social ethnic status which the related person was from and at the same time it made that particular ethnic group influenced towards the supports that was given by a particular ethnic group. By its representativeness of each ethnic group in a structural position, there was no reason for any ethnic groups not to support Otto Ihalauw.

The consequence of the representativeness of the ethnic group in order to fill the structural bureaucracy was the emergence of the reciprocal benefits between the bureaucrats who were in a structural position and the members of ethnic groups where the bureaucrats were from. The bureaucrats would make efforts so that they remained at the same position, but at the same time they should consider the aspiration of the ethnic group's needs and fulfil the economic materials that were sometimes required by the members of the group. In this condition, the bureaucrat positions became the source of economy and self-prestige of the ethnic members.

Approaching the election of Pilkada in 2010, the composition of Echelon II at the local government of South Sorong was occupied by the bureaucrats from all ethnic groups. Although it was not equal, all the ethnic groups, either the indigenous or new comers were represented in the government structural. The following table describes the distribution of the Echelon II based on the ethnic groups. 
Table: Background of the Echelon II Ethnicity

\begin{tabular}{|c|l|c|}
\hline No & \multicolumn{1}{|c|}{ Ethnic Groups } & Amount \\
\hline 1 & Tehit & 10 \\
2 & Imekko & 3 \\
3 & Maybrat & 8 \\
4 & Non-Papua & 6 \\
\hline & Total & $\mathbf{2 7}$ \\
\hline
\end{tabular}

Source: BKD of South Sorong District, 2010, processed.

Something interesting about the previous table was that the distribution of the ethnic background of the Echelon II was not equal among the ethnic group members. Imekko as one of the biggest ethnic group only got 3 chairs in the position of echelon II. This condition did not cause a challenge for Imekko people because they realized they were limited in the bureaucrat resources as to fulfil the requirements for the stratification according to rank. Because the Echelon II structural from Immeko was less than those from other ethnic groups, Otto Ihalauw placed Imekko people in enough numbers in the lower echelon, that was Echelon III (Suroso, interview, 24 July 2010). ${ }^{13}$

The fulfilment of the structure was based on the equality of the representativeness of the ethnicity and it was also implemented in the fulfilment of the position of the head of the district with the econsideration that the position was relatively strategic to raise the supports. Even the position of the head of the district was more strategic than the structural position because the position of the head of the district was closer and sometimes directly related with the community. The following table indicates the origin of the officials where they were from.

13 The interview with Suroso, the Secretary of Bappeda South Sorong district, in Teminabuan - South Sorong. 
Table: Ethnicity Background of the Head of the District

\begin{tabular}{|c|l|l|l|}
\hline No & \multicolumn{1}{|c|}{ Districts } & \multicolumn{1}{|c|}{ Name of the Person } & \multicolumn{1}{|c|}{ Ethnics } \\
\hline 1 & Teminabuan & Mesakh F. Kokurule, S. Pd & Non Papua \\
2 & Wayer & Yohana K. Saul & Non Papua \\
3 & Moswaren & Drs. Yulianus Bosawer, M.Si & Maybrat \\
4 & Seremuk & Karel Sremere, S.Sos & Tehit \\
5 & Inanwatan & George Japsenam & Non Papua \\
6 & Sawiyat & Albert Snahan, S.Sos & Tehit \\
7 & Kokoda & Hengki Gogoba, S.Sos & Imekko \\
8 & Kais & Yakonias Tigore, SE & Imekko \\
9 & Kokoda Utara & Yunus Kokurule, SH & Non Papua \\
10 & Matemani & Marten Nebore, S.IP & Imekko \\
11 & Konda & Izak Meres, SH & Tehit \\
12 & Fkour & Moses Blessia, A.Md. Kes & Tehit \\
13 & Saifi & Simon Sesa & Tehit \\
\hline
\end{tabular}

Source: BKD South Sorong, 2010, processed.

The previous table indicated that most of the heads of the district positions were filled by the officials who had the same ethnic background with the majority who domiciled in the related district. If the position of the head of the district was not occupied by the officials who were of the same ethnic group, or even was occupied by non-Papua, the official who occupied the position of the head of the district was the bureaucrat who had been known by the community in the related district. Therefore, the officials who were placed at the head of the district were relatively easy to raise the supports. The head of the districts were available to raise the supports because they thought that the position that they had was the gift from Otto Ihalauw. When it came to their turn, they returned the gift from Otto Ihalauw in the form of mobilizing support. The raise of the support was easy to be done because the head of the district had the same ethnic group as the majority of the people or had been known by the community in the related district for so long. 
The support raising in the bureaucracy area could be traced back to the process of selection and acceptance of the civil servants. The process also placed ethnicity issues as the main consideration if a candidate would be accepted or not. The ethnicity consideration in the acceptance of civil servants in South Sorong was responded to by the ethnic groups in the form of the willingness to support Otto Ihalauw. These ethnic groups claimed that they were willing to support Otto Ihalauw in the Pilkada contestation if the members of the groups who applied for being civil servants were accepted. ${ }^{14}$

Related with the effort for support raising in the bureaucracy area, Otto Ihalauw in appointing someone to take the position of official also considered their being public figures of the related people in the community. ${ }^{15}$ The consideration was done because it was in line with the patronage relationship that was still applicable in South Sorong. The people being public figures as the officials in the community made the related people have the position as the patron among their communities. This condition made the officials easier to raise supports from their groups to support Otto Ihalauw.

In short, based on the previous explanation, it can be said that the raising of the supports done by Otto Ihalauw was in line with the mechanism in the exchange of kain timur tradition. In raising the supports from bureaucracy, Otto Ihalauw depended on the normative resources more in the form of his rights as the head of the district. The mechanism of the structural appointments and the head of the district can be interpreted as the gift from Otto Ihalauw to the officials who were appointed in those positions. The same things

14 The field findings indicated that there were a lot of potential statements from ethnic groups that supported Otto Ihalauw in the contestation of Pilkada if their group members were accepted as civil servants. One of the proofs was supporting statements from the society of 4 kampongs in Fkour District, these groups stated their supports followed by their requests to Otto Ihalauw as the Bupati (District leader) to accept "anak-anak kami" ("our children") from the 4 kampongs as the civil servants.

15 The officials who supported Otto Ihalauw were the figures (in their ethnic groups) who got sympathy; and the were placed on strategic positions, like the position of the head of Bappeda, the head of Badan Kepegawaian Daerah (Local Staffing Agency), and the heads of the districts. 
happened with the mechanism of the civil workers' acceptance that could be interpreted as the gift from Otto Ihalauw to the ethnic groups where the candidates were from. They who accepted the gift from Otto Ihalauw interpreted it as the debt that should be paid. Meanwhile, for Otto Ihalauw himself, interpreted the gift as the saving or investments in which result would be harvested from the return. The return in the form of support could be interpreted as the payment of the debt from those who once accepted the gift from Otto Ihalauw. Meanwhile, the return in the form of supports was interpreted by Otto Ihalauw as the saving or investment that he made.

\section{b) The Raising of Supports in Political Aspects}

Having the status as the candidate incumbent and the head of Golkar Party, Otto Ihalauw did not find significant difficulties in gaining the political supports. The position as the candidate incumbent and the head of the party indicated that Otto Ihalauw had the normative sources in the form of the rights that were attached in his position. With these sources, Otto Ihalauw did not find difficulties to determine the political party that nominated him as the candidate of the district leader in Pilkada 2010. This was because Golkar Party that he led had 5 chairs in Dewan Perwakilan Rakyat Daerah (DPRD, regional representatives), which means it had fulfilled the requirements as the bearer of political party. ${ }^{16}$ Nevertheless, in nominating Otto Ihalauw, Golkar Party formed coalition with PKS and Hanura Party.

In forming the coalition, Otto Ihalauw got the benefit in the form of relatively big supports because PKS and Hanura Party each had 2 chairs in the DPRD. Meaning, two political parties had

\footnotetext{
16 The political parties or the coalition of political parties can register their candidate if gaining the requirement of at least $15 \%$ of the available chairs. Meanwhile the number of chairs in the DPRD (Local Representatives) of South Sorong were 20 chairs. Therefore, Golkar Party which had 5 chairs ( $25 \%$ of the whole chairs) could nominate their candidate in Pilkada without coalition with the other political parties because they had fulfilled the requirements.
} 
significant supports compared with the other political parties. ${ }^{17}$ Meanwhile the benefits got by PKS and Hanura party was in the form of sympathy from the supporters of Otto Ihalauw. As it was well known, in his position as a candidate incumbent, Otto Ihalauw had a lot of supports because of his success in running the government and development in the first period (2005-2010). PKS and Hanura Party in coalition expected sympathy and supports from the supporters of Otto Ihalauw in the coming legislative election (2014).

In order to gain supports, Otto Ihalauw also created a harmonic relationship with DPRD. Being known as a friendly person and in his position as the leader of Golkar Party which had 5 chairs in DPRD, Otto Ihalauw did not find significant challenges in maintaining the good relationship with DPRD (Suroso, interivew, July 24, 2010 ). ${ }^{18}$ In his position as the current district leader, Otto Ihalauw needed the presence of the government which was stable without the intervention from DPRD as the working partner. With a stable government, Otto Ihalauw was recognized for his ability and success in leading the South Sorong district, and this would increase his eligibility which at its turn would increase his supports in the Pilkada contestation.

Based on the previous illustration, it could be said that Otto Ihalauw used normative sources, personality and skills that he owned to gain political supports. The efforts to form a coalition of political parties and to develop harmonic relationship with DPRD could be said unavoidable from the influence of the exchange of kain timur tradition. Those efforts could be interpreted as the savings or investments of Otto Ihaauw. Meanwhile, the political parties were invited to form the coalition and DPRD interpreted this as the form

17 In addition to Democrate Party, the political parties outside the coalition of Golkar, PKS and Hanura Party had 1 chair in the DPRD of South Sorong.

18 The interview with Suroso, the Secretary of Bappeda of South Sorong, in Teminabuan South Sorong. 
of returning the favour that should be followed up by supporting him in Pilkada 2010.

\section{c) Raising the Support in the Community}

With his personal abilities, normative resources and skills that he owned, Otto Ihalauw as the candidate incumbent raised the supports by the policies that he made. The main purpose of the policies that he enacted was to run the government and develop South Sorong that he led but those policies were also used as a means to raise the community supports. The development policies were wrapped proportionally with the equity issues and this could be interpreted that Otto Ihalauw to proportionally took action for the purpose and needs of the groups that existed in the community. Those proportional policies were responded to positively by each community groups because those policies were assessed relatively just and not harming any particular group.

The policy that relatively stood up was the policy related with the development of the local hospital in Teminabuan. ${ }^{19}$ This policy was based on the consideration of development equalization. This means that Otto Ihalauw as the district leader in any chance always socialized this policy and was directed to increase the health of the community without considering the background where the related people were from. In socializing the policy, Otto Ihalauw always said that the hospital was developed not only for any particular ethnic group. However, the development of the hospital was meant to increase and juxtapose the health service so that the community did not necessarily get treatment away from South Sorong. This hospital development policy was responded to positively because the community did not become worried about the discrimination in

19 Otto Ihalauw took an initiative to develop a hospital at district level because the south area of 'kepala burung' of Papua never got an appropriate hospital, neither in terms of its size nor the equipments nor the medical personnels. By this policy it was expected that South Sorong people and its surroundings did not need to go to Sorong or Manokwari for the health reasons. 
health services.

The community responded that this policy was enacted justly and equally for all members without considering the groups' backgrounds (Thesia, K., interview, July 20, 2010) ${ }^{20}$ In this case, the ethnic groups considered that the policy to develop hospital was a gift from Otto Ihalauw. As a result, these ethnics responded in the form of supports to Otto Ihalauw as the return. Meaning, Otto Ihalauw with the policy to develop a hospital was able to raise the supports that could be used for his intention in the Pilkada contestation that he joined.

In addition to the policy to develop a hospital, Otto Ihalauw also made a breakthrough in the economy, especially the policy related with market development (Suroso, interivew, July 15, 2010). ${ }^{21}$ This was done because the old market was thought to be inappropriate to cover the economic activities which continuously developed. The policy to develop a market created a challenge in the process of moving the sellers to the new market. To encourage the movement to the new market, Otto Ihalauw enacted a new policy to give priorities to the sellers who were in the old market and to the community around the new market by allowing them to take a first pick of the location. This policy apparently gave positive impact towards his image as the leader who was considered to be responsive and responsible towards the needs of the community, especially the sellers.

In addition to the previous policies, Otto Ihalauw also enacted the policy to build up the road and electricity infrastructure,

20 The interviwe with Kenan Thesia, Tehit ethnic, in Teminabuan - South Sorong. In the interview it was stated that "Pembangunan rumah sakit Teminabuan untuk semua anggota masyarakat tanpa memandang dari kelompok mana berasal. Tak ada kelompok yang merasa diperlakukan tidak adil; semua orang merasa senang bisa berobat dan memperoleh pelayanan yang sama". ("The development of the hospital in Teminabuan was for the whole community without considering groups backgrounds. None of the groups felt being treated differently; because all people felt happy being able to get the same treatment.")

21 The interview with Suroso, the Secretary of Bappeda of South Sorong, in Teminabuan South Sorong. 
and the policy in facilitating religious institutions (church) and customs. By these policies, like in the policy about the hospital and market development, Otto Ihalauw gained the needed supports.

Based on the previous illustrations, it can be said that in order to raise the support from the community, Otto Ihalauw used the exchange tradition of kain timur as an instrument to gain support. With his normative sources in the form of his rights as the district leader, Otto Ihalauw enacted the government and development policies for the sake of raising the supports. The government and development policies was interpreted as the savings and investments to generate the supports from the community who got the benefits from the policies. Meanwhile, the requirements to return the gift was interpreted as the debt payments to Otto Ihalauw who had fulfilled the needs of the community by his policies.

\section{d) Raising the Supports in Election Activities}

The raising of supports in the bureaucracy, politics and community as it has been explained previously was happening together with the raising of the supports in election activities (Pilkada). With his normative sources, personal abilities and skills that he owned, Otto Ihalauw raised the supports both in the campaign levels and in the election/voice counting step.

At the campaign level, Otto Ihalawu did not use ethnicity as the main issue to gain supports but instead to uncover the development issue. If the ethnicity issue was nominated as the theme of the campaign, it would be counterproductive for Otto Ihalauw who had a non-Papua background. The development issue was nominated for the theme of the campaign because during his time becoming the leader in the first period, Otto Ihalauw was committed to run the development for the sake of community welfare in South Sorong. Otto Ihalauw tried to be consistent with his commitment, and therefore, in his campaign, he introduced the slogan "developing together with the community."

In order to get more supports, Otto Ihalauw prepared 
campaign materials with the theme development based on the study done by a competent institution or agency, that was Bappeda (Badan Pemerintah Daerah, Local Government Bodies). In preparing the campaign materials the pair of candidates were given input related with development that had been done. The help in the form of information that was for the needs of the campaign could be interpreted that Otto Ihalauw used the normative sources that were in the nation to win Pilkada. This was possible because the position of Otto Ihalauw as the candidate incumbent and Bappeda was the agency that was led by an official who happened to be his close friend (Ihalauw, O., interview, July 21, 2010). ${ }^{22}$

Thus, despite what was mentioned previously, in order to gain the supports and to optimize the campaign, Otto Ihalauw invited the parties' figures who nominated him, either at the national or province level, and also the ethnic figures to campaign. The use of these figures also proved that Otto Ihalauw got supports from political parties who nominated him and from the ethnic groups. The success of Otto Ihalauw in presenting the figures in the campaign could not be separated from the personal sources that he owned, that was his personal ability to maintain personal relationship with those figures.

The discussion of the raising supports in the campaign indicated that Otto Ihalauw used the mechanism of the exchange of kain timur tradition. The campaign theme that was stated by Otto Ihalauw was related with the fulfilment of the needs and the importance of the community. Those campaign themes by the community was interpreted as gifts and for the community, those gifts were the debts that should be returned. Meanwhile, Otto Ihalauw interpreted that the gifts were the form of the savings or investments that in turn resulted in the supports towards him through the mechanism of returning the gifts.

22 The interview with Otto Ihalauw, in Teminabuan - South Sorong. 
At the level of election/the voice counting, the raising of supports was focused to monitor the date of election and the counting. A number of people were prepared as the witnesses to monitor the election and the counting. The determination of witnesses was done with selection that was conducted by the successful teams and those who were selected were the supporters whose loyalty and commitment were not in doubt. Those who were selected as the witnesses got letters of assignments. The meaning of the letter of assignments was to fulfil the administrative requirements and to guarantee the selected people to get reward from Otto Ihalauw. The raising of witnesses done by Otto Ihalauw was in line with the essence of the exchange of kain timur tradition. The loyalty and commitment by the witnesses were considered as the form of gift to Otto Ihalauw and therefore, he was required to return the gifts for the willingness of the witnesses to monitor the election and the counting.

The bottom line explanation was that an actor (candidate) in order to gain supports could use the giving, receiving and returning back mechanisms as manifested in the process of the exchange of kain timur. In the political contexts, the gifts in any forms in the exchange mechanism could be interpreted as the modal for the giver and the modal could be used as an instrument to bind the receiver in order to get supports for political intention of the giver. The more he gives, the more the modal that he had and this later could be predicted as the more supports going to the giver as the capital owner. Also, with the success of the exchange mechanism that presented the supports depended upon the ability of the actor (candidate) to use the sources that he owned.

\section{Closing Remarks}

Based on the study that has been done, it was revealed that the success to gain supports was determined by the ability of the actors (candidates) in making use of the exchange of kain timur tradition. With the resources that was owned, a candidate successfully used 
the exchange of kain timur to gain supports in government and community activities as well as in the election activities.

This study concluded that the tradition that could be used to gain supports was the exchange tradition. The exchange tradition, as well as the exchange of kain timur tradition, presented reciprocal benefit relationship with a patronage pattern between the party who gave and the party who received. The patronage relationship pattern was the explanation of the ongoing supports. In his position as the patron, the party who gave guaranteed the ongoing life of the party who received the gift from the provider. Meanwhile, in his position as a client, the party who received it indicated loyalty for the gift that was received and being loyal was manifested in the form of giving supports to the patron.

In addition, this study also indicated that the raising of the supports could also be explained through the power that existed in the exchange tradition itself. This is because the exchange tradition successfully "locked" the party who received with the responsibility that requested the party who received it to refund the gift in the form of supports.

In short, the tradition that could be used as an instrument to gain support was the exchange tradition in which it had a number of elements at the same time; they were the transactional relationship, debts, and savings and investments. Therefore, in this context the values of tradition that were important were how the economic and political situation worked. These two are attached to the mechanism of the exchange tradition and at its turn would be used as an instrument to mobilize supports to gain power for political sake. Finally, this research indicated that in political studies in Indonesia, the cultural nuance either in the form of ethnic or traditional values still have an important role as the background of the works of local politics and economy. 


\section{References}

Andrain, C.F. (1992). Kehidupan Politik dan Perubahan Sosial. Yogyakarta: Tiara Wacana.

Andrianto, T.T. (2001). Mengapa Papua Bergolak? Yogyakarta: Gama Global Media.

Boellaars, J. (1986). Manusia Irian, Dahulu-Sekarang-Masa Depan. Jakarta: Penerbit PT Gramedia.

Haryanto. (2015). Politik Kain Timur: Instrumen Meraih Kekuasaan. Yogyakarta: PolGov.

Helmke, G., \& Levitsky, H. (2004). Informal Institutions and Comparative Politics: A Research Agenda. Journal Perspectives on Politics, 2(4), 725-740.

Hyde, L. (1983). The Gift, Imagination and The Erotic Life of Property. New York: Vintage Books, A Division of Random House.

Kitschelt, H., \& Wilkinson, S.I. (2007). Citizen-politician linkages: an Introduction. In Kitschelt, H., \& Wilkinson,S.I (eds.), Patron, Clients Policies: Patterns of Democratic Accountability and Political Competition (1-23). New York: Cambridge University Press.

Mansoben, J.R. (1994). Sistem Politik Tradisional di Irian Jaya, Indonesia: Studi Perbandingan, (Doctoral Dissertation). University of Leiden, Leiden.

Massink, J. (2001). Revolusi Kain Timur di Ayamaru. In Pim Schoorl, Belanda di Irian Jaya (375-4770. Jakarta: KITLV - Garba Budaya.

Mauss, M. (1990). The Gift. London: Routledge.

Miedema, J., \& Reesink,G. (2004). One Head, Many Faces. Leiden: KITLV Press.

Ramandey, F.B (ed.). (2008). Mengadili Demokrasi dan Perjuangan Damai Rakyat Papua. Jayapura: LSP - Otsus Papua.

Sangganafa, N., \& Koentjaraningrat. (1994). Pertukaran Kain Timur di Daerah Kepala Burung. In Koentjaraningrat et al. Irian Jaya: Membangun Masyarakat Majemuk (162-166). Jakarta: PT Gramedia Pustaka Utama.

Simandjuntak, D. (2012). Gift and Promises: Patronage democracy in decentralised Indonesia. Journal European Journal of East Asian Studies, II (2012), 99-126.

Sugiono, B et al. (2001). Akar Permasalahan dan Alternatif Proses Penyelesaian Konflik di Papua. In Sayadi (Ed.), Aceh, Jakarta, Papua: Akar Permasalahan dan Penyelesaian Konflik. Jakarta: Yayasan Penguatan Partisipasi Inisiatif dan Kemitraan Masyarakat Sipil Indonesia (YAPPIKA). 
Syarkawi. (2007). Fisibilitas Politik Identitas Dalam Pemilihan Kepala Daerah Secara Langsung (Studi Kasus Pemilihan Gubernur Kalimantan Tengah) (Unpublished Thesis). Program Pasca Sarjana Ilmu Politik Konsentrasi Politik Lokal dan Otonomi Daerah, UGM, Yogyakarta. 